INTERNATIONAL JOURNAL OF RESEARCHES IN BIOSCIENCES, AGRICULTURE AND TECHNOLOGY (c) VISHWASHANTI MULTIPURPOSE SOCIETY (Global Peace Multipurpose Society) R. No. MH-659/13(N) www.ijrbat.in

\title{
INDOOR AIR POLLUTION AND REDUCED LUNG FUNCTION IN WOMEN EXPOSED TO BIOMASS FUEL SMOKE IN RURAL AREA OF SANGLI DISTRICT (MAHARASHTRA)
}

\author{
P.M. Patil \\ Head, Department of Zoology, Dr. Patangrao Kadam Mahavidyalaya, Sangli. \\ Mob.9923492799, email - patilpm16@gmail.com
}

\begin{abstract}
:
In developing countries majority of households uses biomass fuel for cooking and heating purposes which in presence of poor ventilation produces a very high level of indoor air pollution. The smoke released due to incomplete combustion of unprocessed solid biomass fuel contains high volume of health damaging air born pollutants. Such as respirable Particulate Matter (PM), Carbon Mono-oxide (CO), Nitrogen Oxide $\left(\mathrm{NO}_{2}\right)$, Sulfur dioxide $\left(\mathrm{SO}_{2}\right)$ formaldehyde, polycyclic organic hydrocarbons and other some toxic compounds. Inhalation of such air born pollutants causes adverse effect on respiratory system, which reduces lung function and causes Chronic Obstructive Pulmonary Disease (COPD). COPD is the inflammation of bronchi and bronchioles. In COPD if $\mathrm{FEV}_{1} \%<80$ then there is obstructive type of disorder. In this study, we selected 100 women using biomass fuel and 100 women using LPG from rural area Kakadwadi, which is 6 to 7 $\mathrm{km}$ away from Sangli City. Biomass fuel users were considered as Subject and LPG users were considered as control. Survey of women using chulla and LPG was done. Information regarding type of house, type of kitchen, number of years and number of hours exposed to biomass fuel and LPG was collected. Spirometry was done in total 200 women. Spirometric parameters Forced Expiratory Volume per one second ( $\left.\mathrm{FEV}_{1} \%\right)$, Forced Vital Capacity (FVC\%) and ratio of Forced Expiratory Volume per one second / Forced Vital Capacity (FEV 1 / FVC\%) were recorded. We found, out of 100 subject women using chulla 64 women had reduced lung function. In 64 women Forced expiratory volume in one second $\left(\mathrm{FEV}_{1} \%\right)$ is less than $80 \%\left(\mathrm{FEV}_{1} \%<80 \%\right)$ and ratio of $\mathrm{FEV}_{1} \% / \mathrm{FVC} \%<80 \%$. In 64 women obstructive type of Chronic Obstructive Pulmonary Disease (COPD) was found.
\end{abstract}

Keywords: Biomass Fuel, FEV $\%$ (Forced Expiratory Volume per one second), indoor air pollution, forced vital capacity, COPD.

\section{INTRODUCTION:}

In developing countries majority of households uses biomass fuel for cooking and heating purpose. Desai et al. (2004) Cooking is the most important activity contributing to Indoor air pollution. Jin et al. (2005). Wood and other form of biomass, animal dung and crop residues are commonly used as source of energy in developing countries. Albalak et al. (1997) In rural India nearly $90 \%$ of the primary energy is derived from biomass (wood 56\%, crop residues 16\%, dung 21\%) Balkrishna et al. (2002). Three quarters of all households in India use processed biomass as their primary fuel for cooking and among these primary fuel for cooking and among these more than $90 \%$ use either wood or animal dung IIPS (1995).

Due to easy availability of biomass fuel women from rural are uses biomass fuel such as crop residue and wood for cooking heating purpose. Kitchens are not properly ventilated. Incomplete combustion of biomass fuel release smoke which contains high volume and number of air pollutantants such as $\mathrm{PM}, \mathrm{CO}, \mathrm{NO}_{2}, \mathrm{SO}_{2}$. Inhalation of smoke causes adverse effect on respiratory system, it reduces the lung function that is Forced expiratory volume in one second causes COPD and ratio $\mathrm{FEV} 1 \% / \mathrm{FVC} \%<$ $80 \%$.

\section{Objectives:}

- Survey of women using chulla and LPG from rural area Kakadwadi of Sangli district.

- To estimate forced expiratory volume per one second in percentage, $\left(\mathrm{FEV}_{1} \%\right)$, Forced Vital Capacity in percentage (FVC\%) and Ratio of forced expiratory volume per one second and Forced Vital Capacity in Percentage $\left(\mathrm{FEV}_{1} / \mathrm{FVC} \%\right)$. 


\section{MATERIAL METHODS:}

For this study we selected Kakadwadi rural area of Sangli district, which is 6 to $8 \mathrm{~km}$ away from Sangli City. Survey of women using chulla and LPG was done from this rural area. We selected 100 women using chulla and LPG. All women participated in this study are above 35 yrs of age and are from low socio economic status. Information regarding type of house, type of kitchen, number of hours and number of years exposed to biomass fuel and LPG was collected. Spirometery was done in total 200 women. Spirometric parameters Forced Expiratory Volume in One Second $\left(\mathrm{FEV}_{1} \%\right)$, Forced Vital Capacity (FVC\%) and ratio of $\mathrm{FEV}_{1} / \mathrm{FEV} \%$ were recorded.

STATISTICAL ANALYSIS: (Gupta and Kappor, 1983)

\section{i) Calculated $\mathbf{Z}$ test based on null hypothesis:}

The formula and interpretation of $Z$ test is :

$\operatorname{Cal}|z|=\left[\frac{\overline{x_{1}}-\overline{x_{2}}}{\sqrt{\frac{\sigma 1^{2}}{n_{1}}+\frac{\sigma 2^{2}}{n_{2}}}}\right]$

$\bar{x}_{1}$ Mean of Control $\overline{x_{2}}$ Mean of Subject

$\overline{\sigma_{1}}$ Standard deviation of Control

$\overline{\sigma_{2}}$ Standard deviation of subject

$\mathrm{n}_{1}=$ Number of observations of control

$\mathrm{n}_{2}=$ Number of observations of subject

$\mathrm{H}_{0}$ : There is no significant difference between control and subject women $\mathrm{FEV}_{1}$.

Vs

$\mathrm{H}_{1}$ : There is significant difference between control and subject women $\mathrm{FEV}_{1}$.

Cal $|Z|=>$ table $Z=1.96$ at $5 \%$ level of significance. If $Z$ value is greater than table value 1.96 then

$\therefore$ Reject $\mathrm{H}_{0}$

$\therefore$ There is significance difference between control and subject.

\section{OBSERVATION:}

From Table No.1 it is observed that 100 women using LPG, live in concrete house and use indoor kitchen. From this 90 women using LPG for greater than 4 years and 10 women using LPG less than 4 years. 86 women using LPG for more than 15 years and 14 women using LPG less than 15 years. From control group 99 women are literate and 1 woman is illiterate.

From Table No. 2 in subject group it is observed that 83 women using Biomass fuel, wood and 17 women using wood and dung. 97 women living in kutcha type of houses and 3 women in semikutcha type of house. Total 100 subject women using indoor kitchen. 86 women exposed to biomass fuel for more than 15 years and 14 women exposed to biomass fuel for less than 15 years. 87 women exposed to biomass fuel for greater than 6 hours and 13 women exposed to biomass fuel for less than 6 hours. In subject group 96 women were illiterate and 4 women were literate.

Observations on spirometry (in percentage) of women exposed to biomass fuel from Kakadwadi village

Table No.3 represents observations on Age, years of exposure and spirometry (in percentage) of control and Subject women in the village Kakadwadi. 100 women using LPG (Control) and 100 women using chulla (Subject) from village Kakadwadi were selected for the study of spirometry. The values of Age, years of exposure and the values of $\mathrm{FEV}_{1} \%$, $\mathrm{FVC} \%, \mathrm{FEV}_{1} / \mathrm{FVC} \%$ in percentage of each control and Subject women were recorded in Table No. 3. The mean values and $Z$ values of Age, years of exposure and $\mathrm{FEV}_{1} \%, \mathrm{FVC}_{0}, \mathrm{FEV}_{1} / \mathrm{FVC} \%$ from this table are as below.

The mean values of Age and years of exposure of control women are 41.50 and 21.77. While mean values of Age and year of exposure of subject women are 42.62 and 22.44. The mean values of $\mathrm{FEV}_{1} \%$, $\mathrm{FVC} \%, \mathrm{FEV}_{1} / \mathrm{FVC} \%$, of control women are 97.83, 
90.94 and 86.10 respectively, the mean values of $\mathrm{FEV}_{1} \%, \mathrm{FVC} \%, \mathrm{FEV}_{1} / \mathrm{FVC} \%$ of Subject women are $68.05,76.21$ and 77.04 respectively. These values are shown at the base of each column in the Table No. 1.

The calculated $Z$ value of Age and years of exposure and calculated $Z$ value of $\mathrm{FEV}_{1} \%, \quad \mathrm{FVC} \%$, $\mathrm{FEV}_{1} / \mathrm{FVC} \%$ based on null hypothesis are at the last of each column in the Table No.3. The calculated $Z$ value of Age and years of exposure are 1.88 and 0.93. The calculated $Z$ values of Age and years of exposure are less than table value 1.96 hence there is no significant difference in age and year of exposure of control and subject women. While calculated $Z$ values of $\mathrm{FEV}_{1} \%, \quad \mathrm{FVC} \%$ and $\mathrm{FEV}_{1} / \mathrm{FVC} \%$ are $9.97,4.81$ and 8.77 respectively. The calculated $Z$ values of $\mathrm{FEV}_{1} \%, \quad \mathrm{FVC} \%$, $\mathrm{FEV}_{1} / \mathrm{FVC} \%$ are greater than table value 1.96 hence there is significant difference in $\mathrm{FEV}_{1} \%, \mathrm{FVC} \%$, $\mathrm{FEV}_{1} / \mathrm{FVC} \%$ of control and subject women. The result is significant at $5 \%$ level of significance.

\section{RESULT \& DISCUSSION :}

In present study out of 100 subject women 64 women had $\mathrm{FEV}_{1} \%<80 \%$ and ration of $\mathrm{FEV}_{1} \%$ / FVC $\%<80 \%$. In the rural area of Kakadwadi, women from low socio economic status uses biomass fuel wood and dung. Majority of women exposed to biomass fuel smoke more than 15 yrs and more than 6 hrs per day. These women suffered from COPD which is obstructive type of disorder.

In obstructive type of spirometry pattern there is narrowing of small airway due to chronic inflammation. According to Dennis et al. (1996), Orozco et al. (2006), Caballero et al. (2006) the reduction in $\mathrm{FEV}_{1} \%$ and $\mathrm{FEV}_{1} \% / \mathrm{FVC} \%$ may be due to chronic inhalation of toxic substance emitted during biomass combustion leading to inflammatory changes in (bronchi and bronchioles) $\mathrm{FEV}_{1} \%<80 \%$ and ration of Dutt et al. (1996) reported that the parameters $\mathrm{FEV}_{1} \%$ and $\mathrm{FEV}_{1} \% / \mathrm{FVC} \%$ was significantly lower in biofuel users compared with both kerosene and LPG users.

Mangat et al. (2013) studied pulmonary function tests in rural women exposed to biomass fuel and reported that the lung function parameters $\mathrm{FEV}_{1} \%$ and $\mathrm{FEV}_{1} / \mathrm{FVC} \%$ were significantly lower in the study group exposed to biomass fuel than control.

Similar types of results are observed in present investigation. In this study, 64 women out of 100 women had $\mathrm{FEV}_{1} \%<80 \%$ and $\mathrm{FEV}_{1} / \mathrm{FVC} \%<80 \%$. The results of spirometry of subject and control group shows that there was significant difference in the ' $Z$ ' values of parameters of spirometry $\left(\mathrm{FEV}_{1} \%\right.$ and $\left.\mathrm{FEV}_{1} / \mathrm{FVC} \%\right)$. Statistical analysis showed that ' $\mathrm{Z}$ ' values of $\mathrm{FEV}_{1} \%$ and $\mathrm{FEV}_{1} / \mathrm{FVC} \%$ were significantly reduced in subject group as compared to control group.

\section{CONCLUSION.}

Prolonged exposure to biomass fuel smoke in poorly ventilated kitchen causes reduced lung functions and women suffered from Chronic Obstructive Pulmonary Piseases (COPD). In subject group the type of COPD observed was obstructive. As age and years of exposure increases COPD increases.

\section{REFERANCE :}

Desai, M., Mehta, S., Smith, K. (2004): Indoor smoke from solid fuels: assessing the environmental burden of disease at national and local levels. Geneva, Switzerland. World Health Organization.

Jin, Y., Zhou, Z., He, G., Wei, H., Liu, J., Liu, F., Tang, N., Ying, B., Liu, Y., Hu, G. (2005): Geographical, spatial, and temporal distributions of multiple indoor air pollutants in four Chinese provinces. Environ Sci Technol. 39:9431-9439.

Albalak, R. (1997): Cultural practices and exposure to particulate pollution from indoor biomass cooking: effect on respiratory health and nutritional status among the Aymara Indians of the Bolivian Highlands. Unpublished Doctoral Dissertation, University of Michigan.

Balkrishana, K., Sankar, S., Parikh, J., Padmavathi, R., Srividya, K., Venugopal, V., Prasad, S., Pandey, V.L. (2002): Daily average exposure to respirable particulate matter from 
combustion of biomass fuels in rural households of southern India. Environ health perspect. 110:1069-1075.

International Institute for Population Sciences (IIPS) 1995: National family health survey (MCH and Family planning): India 1992-93. Bombay: International Institute for Population Sciences.

Dennis, R.J., Maldonado, D., Norman, S., Baena, E., \& Martinez, G. (1996): Woodsmoke exposure and risk for obstructive airways disease among women. Chest. 109(1):115-9.

Caballero, A., Torres-Duque, C.A., Jaramillo, C., Bolivar, F., Sanabria, F., Osorio, P., Orduz, C., Guevara, D.P., Maldonado, D. (2008):
Prevalence of COPD in five Colombian cities situated at low, medium, and high altitude (PREPOCOL study). Chest. 133(2):343-349.

Dutta, D., Srinivasa, D.K., Rotti, S.B., Sahai, A., Konar, D. (1996): Effects of indoor air pollution on the respiratory system of women using different fuels for cooking in an urban slum of Pondicherry. Natl Med J India. 9:113117.

Mangat, Empreet., Suchet T., Dashora L.S., Singh Surjit, Chouhan Swati. (2013): Pulmonary function tests in rural women exposed to biomass fuel. International journal of basic and applied physiology (IJBPA). 2(1):83-87.

Survey of LPG using women $(\mathbf{n}=100)$ as per House Type, Kitchen Type, Exposure Time, Exposure Year, Literacy.

\begin{tabular}{|c|c|c|c|c|c|c|c|c|}
\hline \multirow{2}{*}{ Survey } & House type & Kitchen type & Hours Exposure & \multicolumn{2}{|c|}{$\begin{array}{c}\text { Years of } \\
\text { Exposure }\end{array}$} \\
\cline { 2 - 9 } & Concrete & Indoor & $>\mathbf{4}$ & $<\mathbf{4}$ & $\mathbf{> 1 5}$ & $<\mathbf{4}$ & Literate & Illiterate \\
\hline LPG & 100 & 100 & 90 & 10 & 86 & 14 & 99 & 1 \\
\hline Total & 100 & 100 & \multicolumn{2}{|c|}{100} & \multicolumn{2}{|c|}{100} & 100 \\
\hline
\end{tabular}

Survey of Biomass fuel using women $(n=100)$ as per Use of fuel, Type of House, Exposure time, Exposure years, Literacy.

\begin{tabular}{|c|c|c|c|c|c|c|c|c|c|c|c|}
\hline \multirow[b]{2}{*}{ Survey } & \multicolumn{2}{|c|}{$\begin{array}{c}\text { Women } \\
\text { using Type } \\
\text { of Fuel }\end{array}$} & \multicolumn{2}{|c|}{$\begin{array}{c}\text { Women } \\
\text { using } \\
\text { House type }\end{array}$} & \multirow[b]{2}{*}{$\begin{array}{c}\text { Women } \\
\text { using } \\
\text { indoor } \\
\text { Kitchen }\end{array}$} & \multicolumn{2}{|c|}{$\begin{array}{l}\text { No. of women } \\
\text { Exposed for } \\
\text { years }\end{array}$} & \multicolumn{2}{|c|}{$\begin{array}{l}\text { No. of women } \\
\text { Exposed for } \\
\text { hours per day }\end{array}$} & \multicolumn{2}{|c|}{$\begin{array}{c}\text { Data of women } \\
\text { Literacy }\end{array}$} \\
\hline & $\begin{array}{l}\ddot{8} \\
\vdots \\
3\end{array}$ & 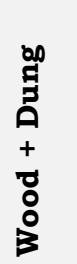 & 起 & 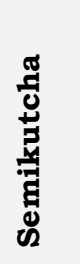 & & $\underset{\substack{n\\
}}{\stackrel{n}{n}}$ & 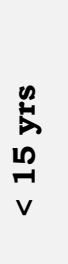 & 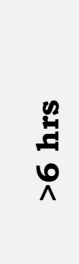 & $\begin{array}{l}0 \\
\stackrel{2}{2} \\
0 \\
v\end{array}$ & 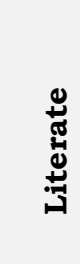 & 䒿 \\
\hline $\begin{array}{l}\text { Biomass } \\
\text { fuel }\end{array}$ & 83 & 17 & 97 & 3 & 100 & 86 & 14 & 87 & 13 & 4 & 96 \\
\hline Total & \multicolumn{2}{|c|}{100} & \multicolumn{2}{|c|}{100} & 100 & \multicolumn{2}{|c|}{100} & \multicolumn{2}{|c|}{100} & \multicolumn{2}{|c|}{100} \\
\hline
\end{tabular}


Table No. - 3

Data of Spirometry (FEV $\%$, FVC\%, FEV 1 FVC\%) of Rural Women from Kakadwadi Exposed to Biomass smoke

\begin{tabular}{|c|c|c|c|c|c|c|c|c|c|c|}
\hline \multirow[b]{2}{*}{ Sr. No. } & \multicolumn{5}{|c|}{ CONTROL } & \multicolumn{5}{|c|}{ SUBJECT } \\
\hline & Age & Years & FEV $_{1} \%$ & FVC\% & $\begin{array}{l}\text { FEV }_{1 /} \\
\text { FVC } \%\end{array}$ & Age & Years & $\operatorname{FEV}_{1} \%$ & FVC\% & $\begin{array}{l}\text { FEV } 1 / \\
\text { FVC\% }\end{array}$ \\
\hline 1 & 38 & 12 & 82.56 & 61.07 & 83.04 & 38 & 20 & 57.27 & 60.82 & 79.75 \\
\hline 2 & 40 & 20 & 98.03 & 91.30 & 88.69 & 45 & 21 & 98.03 & 125.37 & 88.69 \\
\hline 3 & 38 & 21 & 95.54 & 91.43 & 86.16 & 58 & 38 & 77.82 & 99.00 & 78.61 \\
\hline 4 & 39 & 20 & 82.56 & 61.07 & 83.04 & 38 & 20 & 73.94 & 98.00 & 75.45 \\
\hline 5 & 46 & 27 & 121.33 & 114.67 & 86.26 & 45 & 27 & 21.56 & 25.74 & 69.23 \\
\hline 6 & 43 & 13 & 98.03 & 91.30 & 88.69 & 42 & 14 & 67.02 & 99.00 & 67.70 \\
\hline 7 & 37 & 18 & 79.00 & 61.07 & 79.53 & 52 & 32 & 21.56 & 25.74 & 69.23 \\
\hline 8 & 45 & 26 & 98.03 & 91.30 & 88.69 & 49 & 30 & 54.46 & 67.47 & 69.05 \\
\hline 9 & 40 & 20 & 98.03 & 91.30 & 88.69 & 50 & 31 & 61.43 & 77.69 & 66.15 \\
\hline 10 & 48 & 14 & 121.33 & 114.67 & 86.26 & 45 & 26 & 61.43 & 77.69 & 66.15 \\
\hline 11 & 47 & 28 & 101.27 & 96.37 & 86.02 & 45 & 27 & 76.23 & 99.25 & 76.81 \\
\hline 12 & 42 & 23 & 68.00 & 114.67 & 48.34 & 50 & 30 & 58.28 & 63.45 & 76.00 \\
\hline 13 & 36 & 20 & 101.27 & 96.37 & 86.02 & 47 & 26 & 50.00 & 58.15 & 70.09 \\
\hline 14 & 38 & 21 & 92.79 & 91.43 & 86.16 & 49 & 30 & 21.56 & 25.74 & 69.23 \\
\hline 15 & 42 & 11 & 121.33 & 114.67 & 86.26 & 40 & 17 & 54.46 & 67.47 & 69.05 \\
\hline 16 & 38 & 20 & 101.27 & 96.37 & 86.02 & 45 & 26 & 61.43 & 77.69 & 66.15 \\
\hline 17 & 41 & 22 & 98.03 & 91.30 & 88.69 & 41 & 24 & 53.37 & 102.01 & 52.32 \\
\hline 18 & 43 & 23 & 87.58 & 86.26 & 88.47 & 55 & 37 & 51.54 & 53.22 & 73.63 \\
\hline 19 & 41 & 24 & 87.33 & 58.93 & 79.39 & 45 & 25 & 54.46 & 67.47 & 69.05 \\
\hline 20 & 39 & 12 & 121.33 & 114.67 & 86.26 & 45 & 14 & 71.19 & 96.36 & 73.88 \\
\hline 21 & 42 & 22 & 98.03 & 91.30 & 88.69 & 43 & 26 & 30.43 & 40.36 & 75.40 \\
\hline 22 & 45 & 26 & 101.27 & 96.37 & 86.02 & 45 & 22 & 98.03 & 135.48 & 88.69 \\
\hline 23 & 40 & 20 & 92.79 & 91.43 & 86.16 & 40 & 19 & 52.21 & 78.36 & 66.63 \\
\hline 24 & 43 & 23 & 82.56 & 61.07 & 83.04 & 45 & 13 & 101.27 & 96.37 & 86.02 \\
\hline 25 & 42 & 23 & 87.58 & 86.26 & 88.47 & 50 & 30 & 95.54 & 91.43 & 86.16 \\
\hline 26 & 40 & 21 & 121.33 & 114.67 & 86.26 & 39 & 21 & 68.80 & 88.36 & 77.86 \\
\hline 27 & 38 & 12 & 87.58 & 86.26 & 88.47 & 38 & 18 & 121.33 & 114.67 & 86.26 \\
\hline 28 & 39 & 20 & 98.03 & 91.30 & 88.69 & 40 & 19 & 63.11 & 82.06 & 76.91 \\
\hline 29 & 43 & 26 & 87.58 & 86.26 & 88.47 & 38 & 17 & 92.79 & 91.43 & 86.16 \\
\hline 30 & 45 & 27 & 121.33 & 114.67 & 86.26 & 46 & 25 & 121.33 & 114.67 & 86.26 \\
\hline 31 & 48 & 29 & 101.27 & 96.37 & 86.02 & 38 & 22 & 76.23 & 96.63 & 78.89 \\
\hline 32 & 41 & 23 & 82.56 & 61.07 & 83.04 & 36 & 19 & 49.22 & 63.45 & 76.00 \\
\hline 33 & 49 & 12 & 98.03 & 91.30 & 88.69 & 45 & 25 & 21.56 & 25.74 & 69.23 \\
\hline 34 & 40 & 20 & 82.56 & 39.29 & 129.09 & 41 & 20 & 87.58 & 86.26 & 88.47 \\
\hline 35 & 49 & 30 & 98.03 & 91.30 & 88.69 & 48 & 30 & 87.33 & 58.72 & 79.39 \\
\hline 36 & 46 & 29 & 87.58 & 86.26 & 88.47 & 40 & 20 & 87.58 & 86.26 & 88.47 \\
\hline 37 & 43 & 27 & 98.03 & 91.30 & 88.69 & 45 & 23 & 98.03 & 91.30 & 88.69 \\
\hline
\end{tabular}




\begin{tabular}{|c|c|c|c|c|c|c|c|c|c|c|}
\hline \multirow[b]{2}{*}{ Sr. No. } & \multicolumn{5}{|c|}{ CONTROL } & \multicolumn{5}{|c|}{ SUBJECT } \\
\hline & Age & Years & $\mathrm{FEV}_{1} \%$ & FVC\% & $\begin{array}{l}\text { FEV }_{1 /} \\
\text { FVC } \%^{2}\end{array}$ & Age & Years & FEV $_{1} \%$ & FVC\% & $\begin{array}{l}\text { FEV }_{1 /} \\
\text { FVC\% }\end{array}$ \\
\hline 38 & 49 & 14 & 121.33 & 114.67 & 86.26 & 40 & 20 & 98.03 & 91.30 & 88.69 \\
\hline 39 & 47 & 29 & 101.27 & 96.37 & 86.02 & 48 & 27 & 52.59 & 71.63 & 73.42 \\
\hline 40 & 40 & 21 & 101.27 & 96.37 & 86.02 & 40 & 20 & 101.27 & 96.37 & 86.02 \\
\hline 41 & 48 & 30 & 121.33 & 114.67 & 86.26 & 50 & 30 & 95.54 & 91.43 & 86.16 \\
\hline 42 & 42 & 24 & 121.33 & 114.67 & 86.26 & 55 & 14 & 50.00 & 58.15 & 70.09 \\
\hline 43 & 40 & 23 & 98.03 & 91.30 & 88.69 & 43 & 21 & 94.67 & 114.67 & 67.30 \\
\hline 44 & 44 & 27 & 87.58 & 86.26 & 88.47 & 45 & 27 & 53.37 & 73.36 & 72.75 \\
\hline 45 & 42 & 24 & 87.33 & 90.66 & 79.39 & 41 & 23 & 54.46 & 67.47 & 69.05 \\
\hline 46 & 54 & 36 & 73.79 & 80.49 & 76.77 & 42 & 23 & 48.55 & 53.22 & 73.63 \\
\hline 47 & 44 & 24 & 101.27 & 96.37 & 86.02 & 48 & 30 & 21.56 & 25.74 & 69.23 \\
\hline 48 & 38 & 20 & 92.79 & 91.43 & 86.16 & 45 & 14 & 82.00 & 71.85 & 83.04 \\
\hline 49 & 49 & 30 & 87.58 & 86.26 & 88.47 & 38 & 20 & 30.43 & 41.12 & 74.00 \\
\hline 50 & 42 & 24 & 92.79 & 91.43 & 86.16 & 41 & 21 & 92.79 & 91.43 & 86.16 \\
\hline 51 & 41 & 20 & 92.79 & 91.43 & 86.16 & 43 & 22 & 21.56 & 25.74 & 69.23 \\
\hline 52 & 38 & 18 & 82.56 & 61.07 & 83.04 & 40 & 20 & 92.79 & 91.43 & 86.16 \\
\hline 53 & 38 & 13 & 78.00 & 61.07 & 78.36 & 38 & 18 & 121.33 & 114.67 & 86.26 \\
\hline 54 & 39 & 17 & 87.33 & 58.51 & 79.39 & 42 & 25 & 54.46 & 67.47 & 69.05 \\
\hline 55 & 43 & 24 & 92.79 & 91.43 & 86.16 & 45 & 20 & 51.64 & 72.62 & 71.11 \\
\hline 56 & 41 & 21 & 82.56 & 61.07 & 83.04 & 39 & 14 & 95.07 & 88.54 & 86.16 \\
\hline 57 & 36 & 18 & 95.54 & 91.43 & 86.16 & 40 & 20 & 21.56 & 25.74 & 69.23 \\
\hline 58 & 38 & 19 & 83.04 & 61.07 & 83.04 & 37 & 18 & 121.33 & 114.67 & 86.26 \\
\hline 59 & 37 & 14 & 87.33 & 90.66 & 79.39 & 40 & 17 & 87.33 & 89.67 & 79.39 \\
\hline 60 & 36 & 17 & 92.79 & 91.43 & 86.16 & 45 & 24 & 87.58 & 86.26 & 88.47 \\
\hline 61 & 38 & 20 & 83.04 & 61.07 & 83.04 & 38 & 20 & 54.46 & 67.47 & 69.05 \\
\hline 62 & 41 & 21 & 83.04 & 61.07 & 83.04 & 45 & 28 & 21.56 & 25.74 & 69.23 \\
\hline 63 & 39 & 23 & 98.03 & 91.30 & 88.69 & 38 & 19 & 61.43 & 77.69 & 66.15 \\
\hline 64 & 42 & 26 & 121.33 & 114.67 & 86.26 & 40 & 14 & 53.37 & 69.36 & 76.95 \\
\hline 65 & 37 & 20 & 121.33 & 114.67 & 86.26 & 48 & 30 & 55.36 & 71.61 & 77.31 \\
\hline 66 & 44 & 28 & 71.00 & 36.36 & 103.89 & 37 & 19 & 98.03 & 91.30 & 88.69 \\
\hline 67 & 40 & 24 & 92.79 & 91.43 & 86.16 & 39 & 20 & 56.74 & 72.41 & 78.36 \\
\hline 68 & 39 & 21 & 101.27 & 96.37 & 86.02 & 47 & 30 & 21.56 & 25.74 & 69.23 \\
\hline 69 & 40 & 14 & 87.58 & 86.26 & 88.47 & 38 & 20 & 98.03 & 91.30 & 88.69 \\
\hline 70 & 39 & 23 & 121.33 & 114.67 & 86.26 & 38 & 17 & 51.82 & 65.78 & 78.78 \\
\hline 71 & 44 & 27 & 101.27 & 96.37 & 86.02 & 38 & 18 & 54.38 & 73.36 & 74.13 \\
\hline 72 & 48 & 30 & 101.27 & 96.37 & 86.02 & 42 & 13 & 55.36 & 77.56 & 71.38 \\
\hline 73 & 37 & 20 & 92.79 & 91.43 & 86.16 & 50 & 25 & 101.27 & 121.57 & 86.02 \\
\hline 74 & 39 & 21 & 121.33 & 114.67 & 86.26 & 42 & 25 & 51.63 & 66.63 & 77.49 \\
\hline 75 & 36 & 20 & 98.03 & 91.30 & 88.69 & 42 & 24 & 53.40 & 67.39 & 79.24 \\
\hline 76 & 41 & 12 & 101.27 & 96.37 & 86.02 & 36 & 18 & 61.43 & 77.69 & 66.15 \\
\hline
\end{tabular}




\begin{tabular}{|c|c|c|c|c|c|c|c|c|c|c|}
\hline \multirow[b]{2}{*}{ Sr. No. } & \multicolumn{5}{|c|}{ CONTROL } & \multicolumn{5}{|c|}{ SUBJECT } \\
\hline & Age & Years & FEV $_{1} \%$ & FVC\% & $\begin{array}{l}\text { FEV }_{1 /} \\
\text { FVC } \%\end{array}$ & Age & Years & FEV $_{1} \%$ & FVC\% & $\begin{array}{l}\text { FEV }_{1 /} \\
\text { FVC } \%\end{array}$ \\
\hline 77 & 38 & 20 & 98.03 & 91.30 & 88.69 & 38 & 20 & 95.54 & 92.18 & 86.16 \\
\hline 78 & 40 & 25 & 87.58 & 86.26 & 88.47 & 40 & 14 & 121.33 & 114.67 & 86.26 \\
\hline 79 & 39 & 20 & 98.03 & 91.30 & 88.69 & 43 & 22 & 83.53 & 77.73 & 83.04 \\
\hline 80 & 43 & 25 & 87.33 & 90.66 & 79.39 & 45 & 23 & 54.63 & 71.79 & 76.10 \\
\hline 81 & 41 & 24 & 87.33 & 90.66 & 79.39 & 48 & 30 & 61.43 & 77.69 & 66.15 \\
\hline 82 & 40 & 22 & 121.33 & 114.67 & 86.26 & 40 & 21 & 92.79 & 91.43 & 86.16 \\
\hline 83 & 39 & 21 & 87.33 & 90.66 & 79.39 & 38 & 14 & 111.66 & 114.67 & 86.26 \\
\hline 84 & 38 & 20 & 98.03 & 91.30 & 88.69 & 37 & 21 & 55.31 & 73.36 & 75.40 \\
\hline 85 & 41 & 21 & 121.33 & 114.67 & 86.26 & 50 & 30 & 58.36 & 76.63 & 76.16 \\
\hline 86 & 44 & 13 & 101.27 & 96.37 & 86.02 & 42 & 22 & 87.33 & 58.10 & 79.39 \\
\hline 87 & 41 & 23 & 101.27 & 96.37 & 86.02 & 40 & 23 & 57.27 & 60.82 & 79.75 \\
\hline 88 & 38 & 20 & 92.79 & 91.43 & 86.16 & 43 & 26 & 54.46 & 67.47 & 69.05 \\
\hline 89 & 48 & 31 & 121.33 & 114.67 & 86.26 & 41 & 18 & 21.56 & 25.74 & 69.23 \\
\hline 90 & 39 & 21 & 98.03 & 91.30 & 88.69 & 42 & 25 & 54.46 & 67.47 & 69.05 \\
\hline 91 & 43 & 27 & 92.79 & 91.43 & 86.16 & 40 & 23 & 52.36 & 69.36 & 75.49 \\
\hline 92 & 37 & 20 & 121.33 & 114.67 & 86.26 & 41 & 20 & 70.94 & 91.36 & 77.65 \\
\hline 93 & 48 & 30 & 82.56 & 61.07 & 83.04 & 45 & 26 & 78.40 & 99.36 & 78.90 \\
\hline 94 & 37 & 20 & 98.03 & 91.30 & 88.69 & 38 & 18 & 87.58 & 86.26 & 88.47 \\
\hline 95 & 39 & 14 & 121.33 & 114.67 & 86.26 & 35 & 26 & 70.94 & 92.45 & 76.73 \\
\hline 96 & 45 & 25 & 98.03 & 91.30 & 88.69 & 38 & 23 & 21.56 & 25.74 & 69.23 \\
\hline 97 & 38 & 20 & 121.33 & 114.67 & 86.26 & 40 & 24 & 98.03 & 91.30 & 88.69 \\
\hline 98 & 40 & 21 & 87.58 & 86.26 & 88.47 & 38 & 23 & 98.03 & 91.30 & 88.69 \\
\hline 99 & 41 & 22 & 98.03 & 91.30 & 88.69 & 36 & 18 & 83.53 & 61.07 & 83.04 \\
\hline 100 & 49 & 30 & 121.33 & 114.67 & 86.26 & 40 & 22 & 54.46 & 67.47 & 69.05 \\
\hline Mean & 41.50 & 21.77 & 97.83 & 90.94 & 86.10 & 42.62 & 22.44 & 68.05 & 76.21 & 77.04 \\
\hline Var. & 14.11 & 25.44 & 187.81 & 310.02 & 43.80 & 21.52 & 26.95 & 704.79 & 627.69 & 63.04 \\
\hline Sqrt & 0.60 & 0.72 & 2.99 & 3.06 & 1.03 & & & & & \\
\hline $\mathbf{Z}$ & -1.88 & -0.93 & 9.97 & 4.81 & 8.77 & & & & & \\
\hline
\end{tabular}


Figure No. 1: Data of Spirometry (FEV $\%$, FVC\%, FEV 1 /FVC\%) of Rural Women from Kakadwadi Exposed to Biomass smoke

Mean of Spirometry Age, Year of exposure $\mathrm{FEV}_{1} \%$, $\mathrm{FVC} \%$, $\mathrm{FEV}_{1} / \mathrm{FVC} \%$ of Rural Women from Kakadwadi Exposed to Biomass smoke

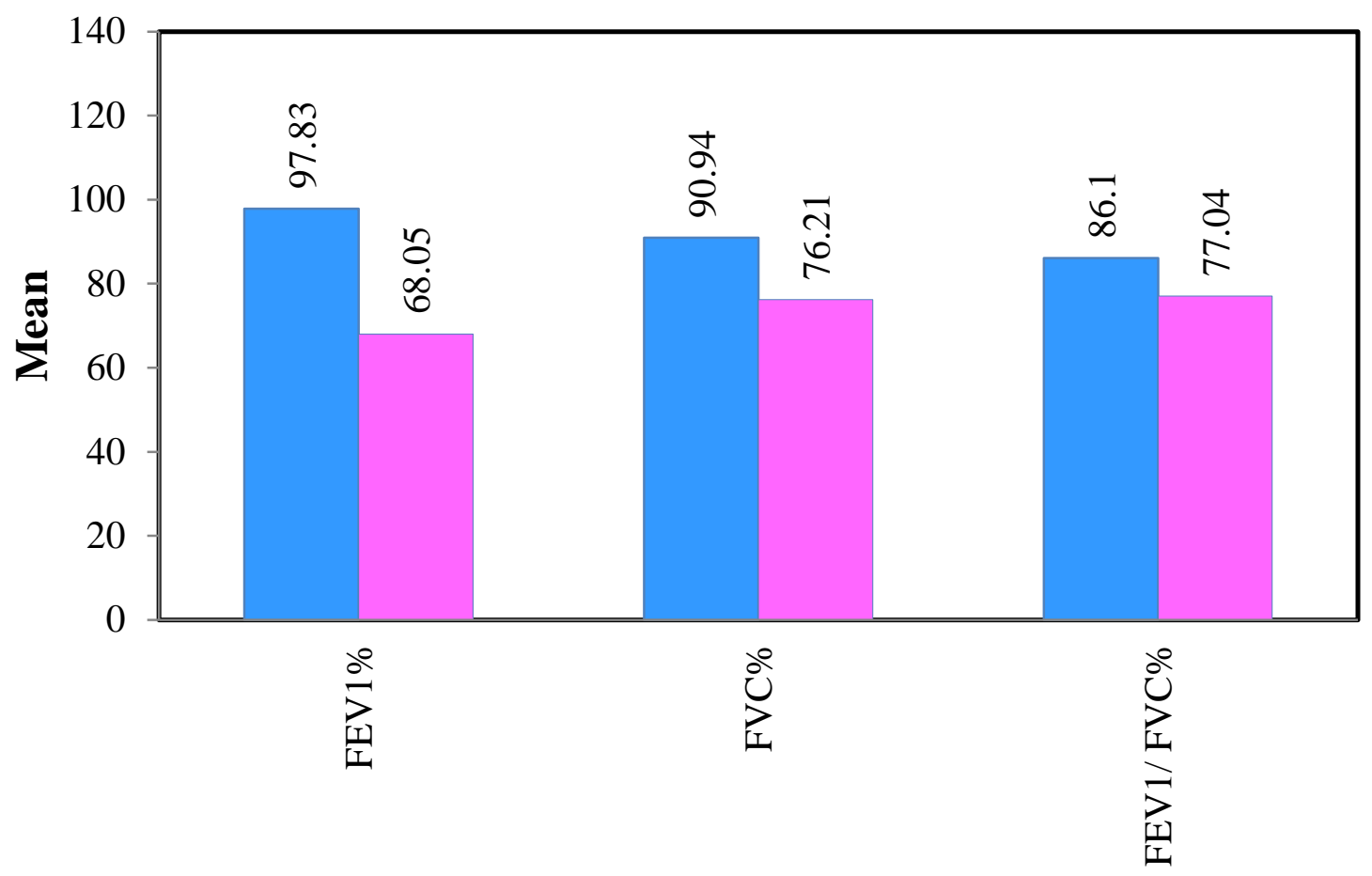

Control $\square$ Subject 